\title{
Limulitella tejraensis, a new species of limulid (Chelicerata, Xiphosura) from the Middle Triassic of southern Tunisia (Saharan Platform)
}

\author{
Błażej Błażejowski, ${ }^{1}$ Grzegorz Niedźwiedzki, ${ }^{2}$ Kamel Boukhalfa, ${ }^{3}$ and Mohamed Soussi ${ }^{4}$ \\ ${ }^{1}$ Institute of Paleobiology, Polish Academy of Sciences, Twarda 51/55, 00-818 Warsaw, Poland 〈bblazej@twarda.pan.pl〉 \\ ${ }^{2}$ Department of Organismal Biology, Evolutionary Biology Center, Uppsala University, Norbyvägen 18A, 75236 Uppsala, Sweden 〈grzegorz. \\ niedzwiedzki@ebc.uu.se \\ ${ }^{3}$ University of Gabes, Faculty of Sciences, City Riadh Zerig 6029 Gabes, Tunisia 〈boukhalfakamel@yahoo.fr〉 \\ ${ }^{4}$ University of Tunis El Manar, Faculty of Sciences, Department of Geology , C.P. 2092 Tunis, Tunisia $\langle$ mohsou@yahoo.fr $\rangle$
}

\begin{abstract}
Numerous well-preserved remains of a new limulid species from the Anisian-lower Ladinian (Middle Triassic) of the Tejra section of southern Tunisia are described. Comparisons are made with limulids from the Triassic deposits of Europe and Australia. The new specimens are congeneric with the type species of Limulitella, but show some morphological differences. Here we describe Limulitella tejraensis new species, a small limulid with semicircular prosoma, small and triangular opisthosoma, well-defined axial ridge, and pleurae along both ridges of the opisthosoma. The Tunisian Limulitella fossils are associated with conchostracans, bivalves, gastropods, and microconchids. Sedimentological and paleontological data from the Tejra section suggest freshwater to brackishwater conditions during the formation of the fossil-bearing interval and the influence of marine transgression into a playa-like environment. Supposed adaptation to the stressful environment sheds new light on the origin and survival of the extant limulines. This is the first report of limulid body fossils from the Triassic of North Africa and the first documentation of Limulitella in the Middle Triassic of northern Gondwanaland.
\end{abstract}

\section{Introduction}

The chelicerate order Xiphosurida, generally known by the colloquial misnomer 'horseshoe crabs,' is among one of the rarest of invertebrate taxa, mostly owing to their unmineralized exoskeleton and predilection for marginal environments that are so rare in the stratigraphic record (Babcock et al., 2000; Loveland and Botton, 2015; Lamsdell, 2016). Thus, the discovery of Middle Triassic horseshoe crab material adds significantly to our understanding of the group. Xiphosurida have existed for $480 \mathrm{Myr}$ (Lamsdell, 2013, 2016), with the earliest unequivocal representatives found in the Upper Ordovician of Manitoba, Canada (Rudkin et al., 2008), apparently preceded by finds of putative Xiphosurida from the Lower Ordovician of Morocco (Van Roy et al., 2010). Only four species of horseshoe crabs exist today, all of which are members of Limulidae Zittel, 1885 ( = Mesolimulidae Størmer, 1952) and characterized by their large crescentic prosomal shield and the fusion of the opisthosomal tergites (Lamsdell and McKenzie, 2015). The recently published study of the Xiphosura (equivalent to total group Xiphosurida) phylogeny (Lamsdell, 2016) has interesting implications. First of all, they suggested that horseshoe crabs have independently invaded the non-marine realm at least five times during their long evolution. Secondly, horseshoe crabs have had rather a complex evolutionary history not only in the Paleozoic, but also in the Mesozoic.
The aim of this paper is to describe a new species of horseshoe crab, Limulitella tejraensis n. sp., from the Middle Triassic of southern Tunisia (Saharan Platform). Limulitella represents the most basal representative of the family Limulidae (Lamsdell, 2016), which is a clade of Triassic to Recent horseshoe crabs that exhibits no vestige of segmentation dorsally in the opisthosoma (Riek and Gill, 1971), and the axis of the thoracetron bears a dorsal keel (Lamsdell, 2016).

\section{Geologic setting}

Triassic deposits of southern Tunisia crop out widely in the Jeffara domain (Fig. 1.1, 1.2). The main outcrops are exposed along a NW-SE trending belt from Jebel Tebaga of Medenine, which includes the Tejra outcrops, to the Libyan border. The Triassic succession is very thick $(>2000 \mathrm{~m})$, especially in the Jeffara Basin, and is dominated in its lower part by red-beds, which usually lie unconformably on upper Permian rocks (Busson, 1967; Bouaziz, 1986; Kilani-Mazraoui et al., 1990; Kamoun et al., 1998, 1999, 2001; Dridi and Maazaoui, 2003). The Tunisian Triassic paleogeographic evolution results from the disassembly of Pangaea in the early Mesozoic, when the North African Platform became a broad Tethyan-facing passive continental margin (Soussi et al., 1998, 2001; Kamoun et al., 2001; Bouaziz et al., 2002; Courel et al., 2003). 


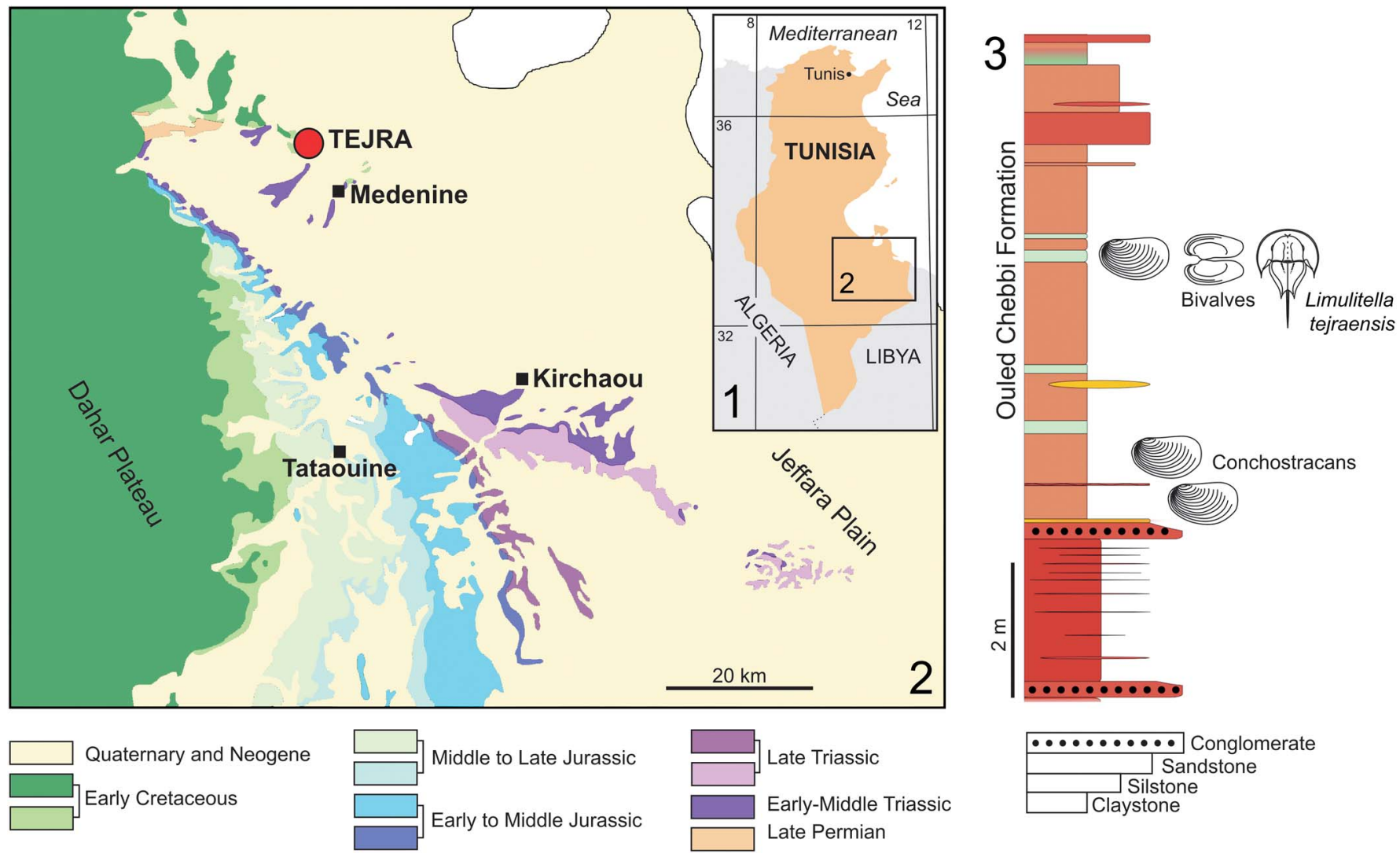

Figure 1. Location of the studied area in Tunisia: $(\mathbf{1}, \mathbf{2})$ geological map of the Jeffara Plain and Dahar Plateau (Medenine/Kirchaou/Tataouine area) with position of the Tejra site; (3) columnar section of the Ouled Chebi Formation exposed at the lower part of the Tejra 2 clay-pit, showing the horizon with occurrence of the studied Limulitella material.

The material studied herein comes from a locality called either Tajera Skhira (e.g., Biely and Rakus, 1991) or Tejra Sghira (e.g., Baccour et al., 2008). The Triassic succession there is exposed in a monoclinal structure with beds dipping southwest. It is unconformably overlain by middle Callovian, shallow-marine Jurassic carbonates. Bed-by-bed logging of the sites around Tejra resulted in construction of a detailed stratigraphic section that is $\sim 100 \mathrm{~m}$ thick. However, only part of this section (the main Tejra outcrop) was analyzed in detail in the field and studied paleontologically (Soussi et al., 2016).

The Tejra section can be subdivided into four distinctive units. The first unit represents the basal part of the section and is $\sim 25 \mathrm{~m}$ thick. It is composed of red claystones comprising gray to green, thin claystones interbedded with numerous medium- to coarse-grained and well-sorted sandstones (Fig. 1.3). Local desiccation features observed are numerous ripple marks on the upper surfaces of thin sandstone layers. The brown and green claystone horizons encountered at the base of this unit are particularly rich in conchostracans. A succession of two gray-yellow beds bounding a brown bed yielded an abundant and a very diverse freshwater fauna (Fig. 2.1). This is situated $\sim 5 \mathrm{~m}$ above a basal conglomerate, composed of claystones irregularly interbedded with well-sorted and rounded grains of quartz ( 1-2 $\mathrm{mm}$ in diameter). Most of the fossils are derived from yellowish sediments at the top of the lower gray/green bed (Fig. 2.2). The fauna is represented by conchostracans (Fig. 2.3), horseshoe crabs, freshwater bivalves (Fig. 2.4, 2.5), rare microconchids, and lingulides. Desiccation cracks, small burrows, and casts from plant roots are also present in this horizon.

The second unit is $\sim 30 \mathrm{~m}$ thick. It is clay dominated, but contains numerous sandstone interbeds. At the base, two thick layers of medium-grained red sandstone, interbedded with a $2 \mathrm{~m}$ thick red claystone yield a rich fauna of marine or brackish bivalves, microconchids, gastropods, and lingulides.

The third unit is $\sim 35 \mathrm{~m}$ thick. It is composed mainly of reddish-brown siltstones and claystones and comprises a sandstone bed marker in its middle part showing numerous invertebrate ichnofossils in its lower part. The fauna includes conchostracans, lingulides, and rare partially preserved horseshoe crabs, although the latter were found only at the base of the unit.

The fourth unit is $\sim 10 \mathrm{~m}$ thick. It mainly comprises brown claystone with thin green beds and contains a fauna of conchostracans and lingulids, rare gastropods, rare horseshoe crabs, and microconchids. The claystones represent deposition in floodplains and lakes and the associated sandstone and siltstone interbeds are interpreted as deposits resulting from intermittent flood events.

\section{Materials and methods}

The described material comes from two abandoned clay pits in Tejra area near Medenine (Fig. 1). The samples collected in 2013 and 2014 from the Tejra section yielded a total of 

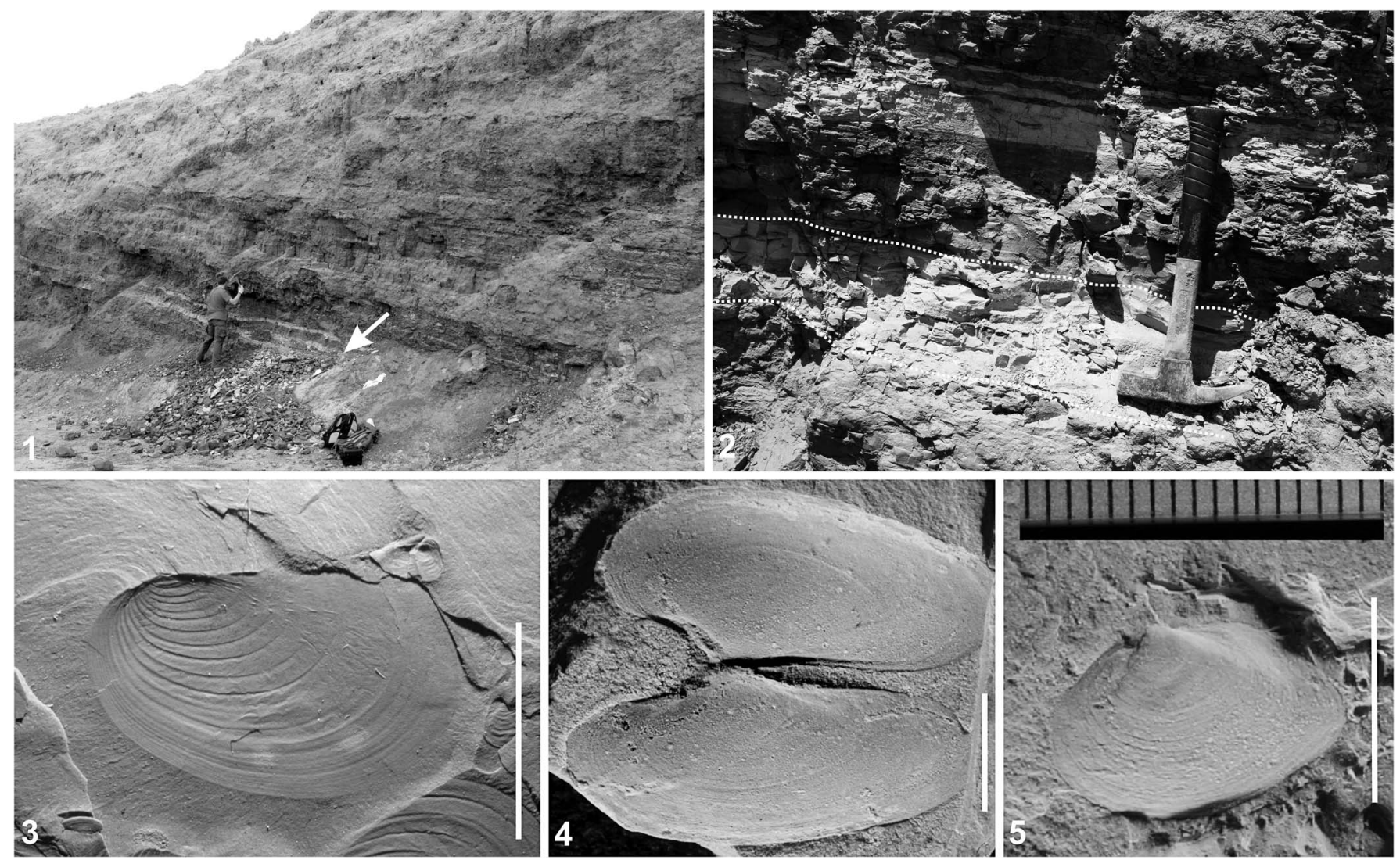

Figure 2. Details of the fossil-bearing strata, lower part of the Tejra section: (1) exploration of fossil-bearing deposits represented by red claystone and siltstone intercalated with thick greenish or yellowish claystone beds from the lower part of the section (arrow indicates freshwater horizon with Limulitella remains) (2) details of the greenish claystone with freshwater fauna; (3) conchostracan from freshwater horizon, large form (species B) described as cf. Dictyonatella sp. (4, 5) Bivalves from the freshwater horizon: (4) Unionites cf. brevis; (5) Unionites cf. longus. Scale bar in (3-5) is $10 \mathrm{~mm}$. Hammer for scale in (2) represents $30 \mathrm{~cm}$.

21 specimens, including one almost completely articulated exoskeleton (Fig. 3.1). The other twenty specimens are incomplete, being preserved as isolated fragments of the prosoma and opisthosoma (Fig. 3.3-3.8). The horseshoe crab-bearing rocks are green, rather poorly lithified claystones and siltstones.

All available biostratigraphic and sedimentologic data comprising the latest developments in the Middle to Upper Triassic rocks of Algeria, Tunisia, and Libya were used for construction of a regional stratigraphic cross section and elaboration of an updated stratigraphic framework (Soussi et al., 2016). Specimens were coated with ammonium chloride and photographed using a Canon EOS 400D digital camera.

Repository and institutional abbreviation.-The collected material is housed at the Institute of Paleobiology, Polish Academy of Science in Warsaw (collection ZPAL V.46).

\section{Systematic paleontology}

Phylum Arthropoda Latreille, 1829

Order Xiphosurida Latreille, 1802

Family Limulidae Zittel, 1885 ( = Mesolimulidae Størmer, 1952) Genus Limulitella Størmer, 1952

Type species.—Limulites bronnii Schimper, 1853.
Diagnosis._-"Mesolimulidae with postmedian margin of genal angle forming an angle with anterolateral margin of narrow subtriangular abdomen, a median keel may occur on axis" (Størmer, 1952, p. 637).

Remarks.-Placement of Limulitella within Limulidae is based upon affinities of that genus with Mesolimulus Størmer, 1952, who allied the two in the Mesolimulidae. Mesolimulidae has subsequently been synonymized with Limulidae (Riek and Gill, 1971). Limulitella has been interpreted by some as being more closely associated with Paleozoic genera embraced within Paleolimulidae Raymond, 1944 (Riek and Gill, 1971; Holland et al., 1975; Feldmann et al., 2011). Although the family placement is not the focus of this work, it is noteworthy that general absence of visible segmentation on the axial part of the opisthosoma argues in favor of placement within the Limulidae. Limulitella Størmer, 1952 ( = Limulites Schimper, 1853) includes: Limulitella cf. liasokeuperinus (Braun, 1860), brackish-marine, Pliensbachian (Early Jurassic) (this particular specimen was lost during World War II); L. vicensis (Bleicher, 1897), marine, Early Triassic; L. henkeli Fritsch, 1906, marine, Early Triassic; L. volgensis Ponomarenko, 1985, brackishmarine, Early Triassic; L. bronnii (Schimper, 1853), Middle Triassic; and three unnamed specimens referred to Limulitella by Hauschke et al. (2004, Madagascar), Hauschke and Wilde (2008, Germany), and Hauschke et al. (2009, the Netherlands). 

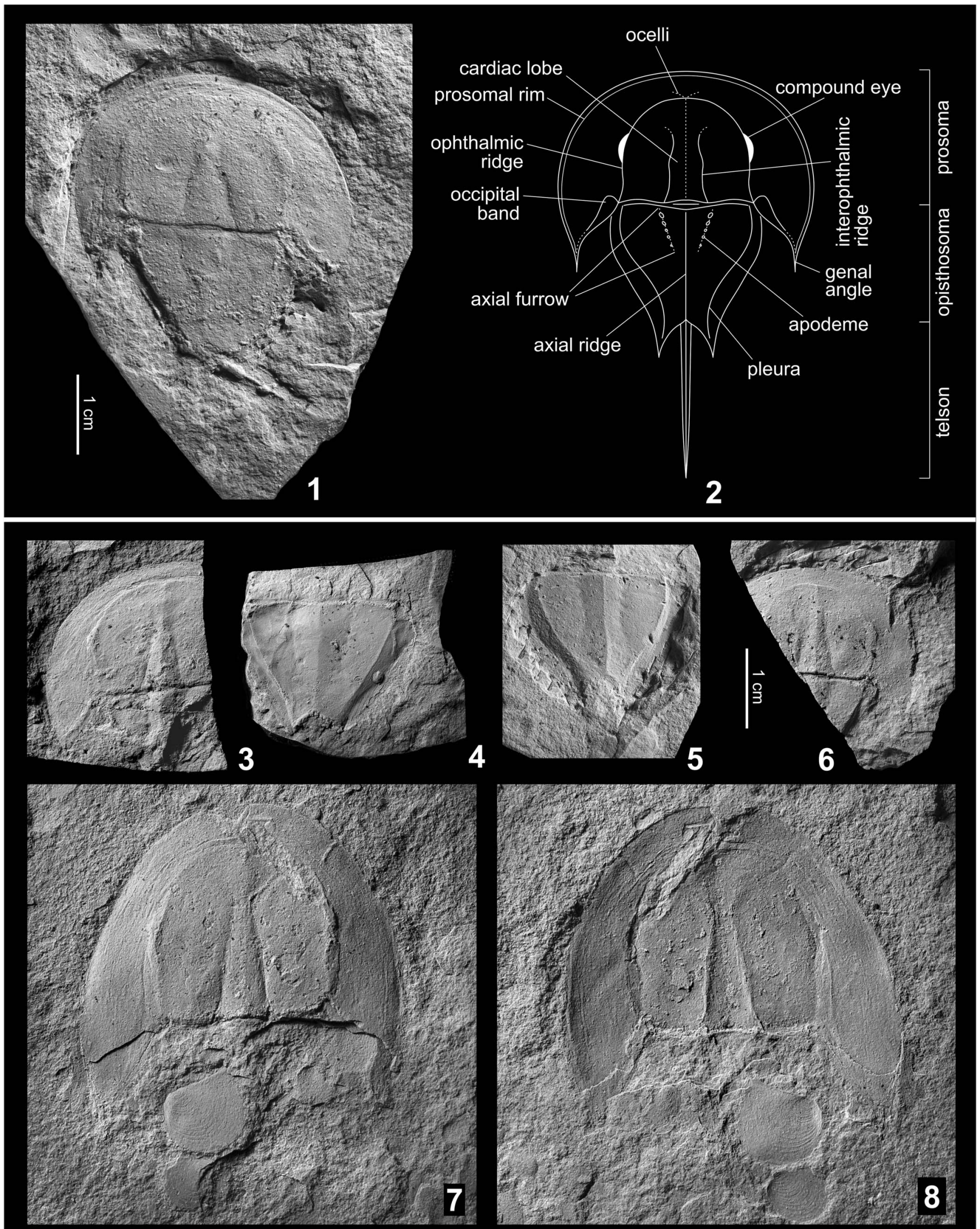

Figure 3. (1) Articulated exoskeleton of the holotype (ZPAL V.46/101p); (2) diagram of morphological features exhibited on the dorsal carapace of Limulitella tejraensis $\mathrm{n}$. sp.; not observed on the holotype are the opisthosomal (moveable) spines; (3) incomplete exoskeleton (ZPAL X.46/106); (4) complete opisthosoma (ZPAL X.46/109); (5) complete opisthosoma (ZPAL X.46/102); (6) incomplete exoskeleton (ZPAL X.46/120); (7, 8) the part (ZPAL X.46/103p) and counterpart (ZPAL X.46/103n) of the flattened, complete prosoma (ZPAL X.46/103p). 


\section{Limulitella tejraensis new species}

Figures 3, 4

\section{Holotype.-ZPAL V.46/101p (Fig. 3.1).}

Type locality and horizon.-Tejra, Ouled Chebbi Formation (Anisian-early Ladinian, Middle Triassic), Medenine area, Sahara Platform, southern Tunisia.

Geographic range.-Known from the type locality only.

Diagnosis.-Prosoma with depressed occipital bands, broad at the ophthalmic ridge becoming thinner and disappearing at the genal spines. Ophthalmic ridge extends in S-shaped line from ocelli along the carapace inner edge as far as the genal angle. Posterior margin of opisthosoma lacks small spines.

Description.-Prosoma wider than long (average length $16.7 \mathrm{~mm}$; average width $31.1 \mathrm{~mm}$ ), weakly to moderately vaulted. Prosomal rim uniform, narrow (Fig. 3.1, 3.3). Anterior margin semicircular, with lateral margins parallel to median axis of carapace, ending posteriorly in long acute genal spines (Fig. 3.7, 3.8). Cardiac lobe smooth, narrowing anteriorly with sinuous margin and obscure nodose anterior, extends $\sim 50 \%$ of prosoma length, terminating anteriorly at slightly visible ocelli (Fig. 3.1, 3.3 3.6, 3.7). Large lateral (compound) eyes posterior to midlength on well-defined ophthalmic ridges (Fig. 3.6, 3.7). Ophthalmic ridge forming rounded structure, inscribing an S-shape within an inner ridge of prosoma to genal spines (Fig. 3.2, 3.7). The genal spines curve inwardly and posteriorly along outer ridge of prosoma. Depressed occipital bands are broad at the ophthalmic ridge, becoming thinner and then disappearing at the genal spines (Fig. 3.1).

Unsegmented opisthosoma small (average length $12.2 \mathrm{~mm}$; average width, $19.1 \mathrm{~mm}$ ), triangular, weakly to moderately vaulted in cross section (Fig. 3.4, 3.5). Axial ridge well defined (Fig. 3.5) in the anterior part, bounded by five pairs of depressed entapophoseal pits (apodemes), decreasing in size posteriorly along diagonal axial furrows. Longitudinal ridges form inner margin of opisthosomal flanks, which are separated from central part of opisthosoma by distinct pleurae. Not observed are the opisthosomal (moveable) spines. Flanks extend along S-shaped pleurae. Posterior margin relatively deep and triangular, terminating in two distinct large marginal spines. Telson triangular in cross section. Venter not preserved in specimens.

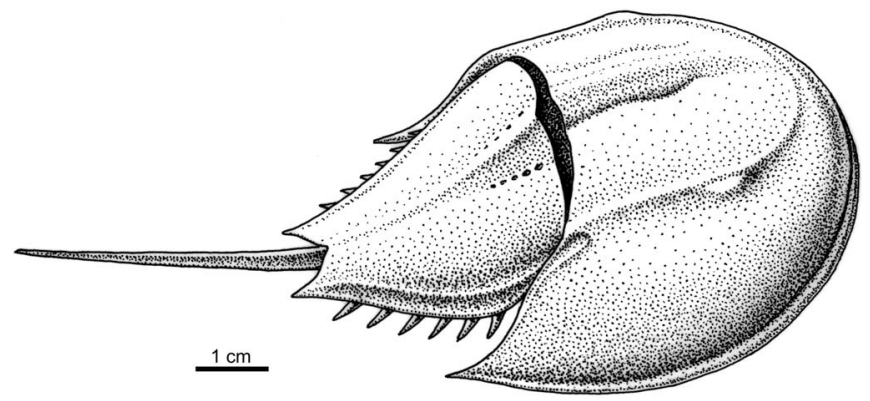

Figure 4. Reconstruction of Limulitella tejraensis n. sp. The movable spines are not present on the fossils.
Etymology.-After the type locality.

Other material.-Five paratypes, ZPAL X.46/102; ZPAL X.46/ 103p,n; ZPAL X.46/106; ZPAL X.46/109; ZPAL X.46/120. Others specimens: ZPAL X.46/104; ZPAL X.46/105; ZPAL X.46/107; ZPAL X.46/108; and ZPAL X.46/110-119.

\section{Discussion}

Comparison of Limulitella tejraensis $n$. sp. with other Triassic limulines.-Triassic horseshoe crabs are considered to have a relatively poor fossil record, with only nine genera having been described: Limulitella Størmer, 1952, known from Germany (Fritsch, 1906; Hauschke and Wilde, 2008), France (Schimper, 1853; Bleicher, 1897), the Netherlands (Hauschke et al., 2009), Madagascar (Hauschke et al., 2004), and Russia (Ponomarenko, 1985); Mesolimulus Størmer, 1952 from Spain (Vía, 1987); Tachypleus Leach, 1819 (=Heterolimulus Vía Boada and De Villalta, 1966) from France; Tarracolimulus Romero and Boada, 1977 from Spain; Psammolimulus Lange, 1923 from Germany (Lange, 1923; Meischner, 1962); Yunnanolimulus Zhang et al., 2009 from south-west China (Hu et al., 2011); Paleolimulus Dunbar, 1923 from Germany (Hauschke and Wilde, 1987, 2000); and two genera described from freshwater strata of Middle Triassic age of New South Wales (Riek, 1968; Pickett, 1984): Australolimulus Riek, 1955 and Dubbolimulus Pickett, 1984. Dubbolimulus has been previously considered to be a synonym of Paleolimulus (Lamsdell, 2016). With respect to the opisthosoma, which is conspicuously smaller than the carapace, the three last genera are quite different from forms described in this paper, and some of them exhibit extremely aberrant morphologies. The opisthosomal (moveable) spines are not present on the described specimens. However, on the reconstruction of Limulitella tejraensis n. sp. we have drawn moveable spines, taking into account the morphologically closest representative of the genus, Limulitella bronnii (Schimper, 1853) from France, illustrated by Gall and Grauvogel-Stamm (1999).

The morphological phylogenetic analyses recently carried out by Lamsdell (2016) demonstrated that Limulitella is a polyphyletic genus. Of all known Triassic horseshoe crabs, Limulitella tejraensis $\mathrm{n}$. sp. seems to be almost identical to the Limulitella forms from France, Germany, and Madagascar. Certainly, the morphological features of $L$. tejraensis are remarkably similar to those of L. bronnii (Schimper, 1853) from France, illustrated by Gall and Grauvogel-Stamm (1999; see also Röhling and Heunisch, 2010). The shape of the ophthalmic ridge, S-shaped inscribing within inner ridge of the prosoma to the characteristic genal angles are the main features that distinguish $L$. tejraensis $\mathrm{n}$. sp. from $L$. bronnii. In both forms, the unsegmented opisthosoma is small with flanks extending along S-shaped pleurae and the posterior margin is significantly cleft triangularly in the posterior part, which in $L$. bronnii bears two shorter distinct marginal spines. The posterior margin of L. tejraensis $\mathrm{n}$. sp. lacks those spines.

Limulitella bronnii was described and sketched by Schimper (1853) from the early Middle Triassic (Anisian) 'Grès à Voltzia' Formation of eastern France, which represents an environment interpreted as a refugium for terrestrial 
communities during the end-Permian mass extinction and its Triassic aftermath (Gall and Grauvogel-Stamm, 2005). In the detailed investigations of Lamsdell (2016), L. bronnii is placed within the Limulidae, next to genera forming the xiphosurid crown group (the extinct Crenatolimulus [Feldmann et al., 2011] and the extant Carcinoscorpius, Limulus, and Tachypleus).

Preservation and habits of Limulitella tejraensis $n$. $s p$.-The state of preservation of the material found at Tejra is not ideal, owing to the nature of its compaction, as indicated by wrinkling along the anterior of the prosomae. The vast majority of the specimens are incomplete (i.e., preserved as isolated prosomal and opisthosomal fragments) and represent all four stages of disarticulation (Fig. 3), as observed by Babcock et al. (2000). The specimens described here are relatively small, and with respect to their presumed close relationship with extant limulines they mostly probably represent the remains of juveniles only. Jurassic horseshoe crabs known from the fossil record seem to represent juvenile forms (Błażejowski, 2015; Błażejowski et al., 2015, 2016). The giant limulid trackways, Kouphichnium lithographicum Oppel, 1862, reported from Germany and France (Schweigert, 1998; Gaillard, 2011) seem to support this interpretation.

Within the strata containing Limulitella tejraensis n. sp., thin-shelled bivalves and clam shrimp (conchostracans) are present (Fig. 3.8), and these may have provided a diet for the horseshoe crabs. The diet of fossil and the modern Atlantic Limulus is highly diverse and consists of a variety of small marine organisms, including soft-shelled bivalves, gastropods, polychaetes, and crustaceans (Botton, 1984; Botton and Ropes, 1989; Kin and Błażejowski, 2014).

Sedimentological and paleontological data from the section that yielded the Limulitella tejraensis $\mathrm{n}$. sp. specimens suggest brackish/freshwater conditions. Forms inhabiting such environments are known from the fossil record since the late Paleozoic (Lamsdell, 2016). In his phylogenetic analysis, Lamsdell (2016) demonstrated that limulines colonized non-marine environments many times throughout their evolutionary history. In addition to the suborder Limulina, the Belinurina are a common component of late Carboniferous to early Permian freshwater/ brackish coal swamps (Filipiak and Krawczyński, 1996; Anderson, 1997; Anderson and Selden, 1997; Lamsdell, 2016). The loss of marine habitat and colonizing of brackish/ freshwater environments are probably direct effects of the turbulent history of shallow-marine ecosystems at the end of Paleozoic (Foster and Twitchett, 2014). Rapidly alternating cool and warm periods during the ensuing Carboniferous Ice Age caused deep changes in the inhabitable environments (DiMichele et al., 2001; Scheffler et al., 2003; Peyser and Poulsen, 2008). Coastlines fluctuated widely owing to local basin subsidence and worldwide sea-level changes (Haq and Shutter, 2008). Continents aggregated, forming Pangea; coastline length decreased; more common deltaic environments supported fewer corals, crinoids, and bryozoans (Stanley and Powell, 2003; Veron, 2008), and many groups of animals, including bivalves, gastropods, bony fish, and horseshoe crabs, were forced to adapt to freshwater/brackish environments
(Wesselingh, 2007; Sallan and Galimberti, 2015; Lamsdell and Selden, 2016).

Environmental conditions changed in the late Permian, when, as a result of decreasing glaciations, the interiors of continents became drier and brackish/freshwater areas were probably reduced (Erwin, 1993; Twitchett et al., 2001; Clarkson et al., 2015). At that time, the largest mass extinction (end-Permian extinction) recorded in the history of life on Earth began (Shen et al., 2006). Although it affected many groups of organisms in many different ecosystems, shallow-marine communities suffered preferentially. The current fossil record indicates that the belinurines did not survive the late Paleozoic environmental changes. A few horseshoe crab taxa, including ancestors of the Triassic genus Limulitella, were presumably so tolerant of changing conditions throughout the late Paleozoic that they survived the end-Permian mass extinction. In the early Mesozoic, the ancestral survivors presumably evolved into the Limulidae horseshoe crab lineage, which survives into modern times. In the Early-Middle Triassic, some lineages with unusual or aberrant morphologies also evolved (e.g., Austrolimulus). The late Early to early Middle Triassic represents a time of recovery following the end-Permian mass extinction (Erwin, 2006; Knoll et al., 2007; Hu et al., 2011; Chen and Benton, 2012). Thus, it can be considered an important stage in the evolution history of Limulina. Despite the poor state of preservation, horseshoe crabs known from the Lower Triassic (Olenekian) from Ankitokazo Basin, Madagascar (Hauschke et al., 2004) and Vetluga Series of Russia (Ponomarenko, 1985) were identified as Limulitella. Worldwide distribution of this group in various localities and different ecosystems provides evidence for rapid adaptive radiation of the group shortly after the biotic crisis, developing adaptive capability for survival in divergent environmental niches. The assumed high degree of environmental tolerance of the genus Limulitella reflects their ability to exist in both marine habitats and freshwater/brackish environments when forced to do so. All three extant genera exhibit a high tolerance to changes of salinity in inhabited areas (Shuster, 1982; Ehlinger and Tankersley, 2009). The Indian species, Carcinoscorpius rotundicauda, is observed to migrate astonishing distances from the mouth up to $150 \mathrm{~km}$ to the source area of the Hooghly (Ganges) River (Annandale, 1922).

Thus, the evolutionary success of horseshoe crabs results in its most important part from the specialization, which played a key role during the re-establishment of the biota after the endPermian extinction event.

\section{Conclusion}

Because xiphosurid arthropods are extremely rare in the fossil record, the recent discovery of the Middle Triassic fossils are of considerable importance in bridging the existing gap in our knowledge of limulid distribution and diversification during the early Mesozoic. The state of preservation and associated fauna indicate that the depositional area may have been a feeding zone for Limulitella tejraensis $\mathrm{n}$. sp. While this new discovery of Triassic horseshoe crabs has only a limited bearing on phylogenetical relationships within the group, it certainly sheds new light on several aspects of the origin of extant 
limulines and the presumed role of specialization during the end of Paleozoic crisis.

\section{Acknowledgments}

We would like to thank, several institutions that have funded our research work in Tunisia. The research in 2013 was supported by the Polish Ministry of Science and Higher Education (grant number 7986/B/P01/2011/40, grant of T. Sulej and G. Niedźwiedzki). We thank R.M. Feldmann (Kent State University) and P. Gieszcz (Independent Center for Advanced Research machinic.it) for many useful suggestions and correction of English. The field study in 2014 was financed by the University of Warsaw through the Advisory Board for Student Scientific Movement (Project: 51/I/2014), the University of Warsaw Students' Union (Project: II/539/1120/2014), the Faculty of Biology of University of Warsaw, the Department of Paleobiology and Evolution of University of Warsaw, and the Foundation of University of Warsaw. G. Niedźwiedzki is currently funded by a grant awarded to P.E. Ahlberg (Uppsala University). We would like to sincerely thank P. Walsh (University of Silesia) for many useful suggestions and linguistic correction. We are also very grateful to M. Tałanda, D. Dróżdż, J. Mermer, K. Biernacki, J. Tałanda, M. Pindakiewicz, and A. Tobolska for their help during fieldwork in 2014. Finally, we are grateful to the UR11 ES 15 from the University of Tunisi El Manar for facilitating the two field missions organized in southern Tunisia in 2014.

\section{References}

Anderson, L.I., 1997, The xiphosuran Liomesaspis from the Montceau-lesMines Konservat-Lagerstätte, Massif Central, France: Neues Jahrbuch für Geologie und Paläontologie, Monatshefte, v. 204, p. 415-436.

Anderson, L.I., and Selden, P.A., 1997, Opisthosomal fusion and phylogeny of Palaeozoic Xiphosura: Lethaia, v. 30, p. 19-31.

Annandale, N., 1922, The marine element in the fauna of Ganges: Amsterdam, Bijdr Dierk, v. 1, p. 143-154.

Babcock, L.E., Merriam, D.F., and West, R.R., 2000, Paleolimulus, an early limuline (Xiphosurida), from Pennsylvanian-Permian Lagerstätten of Kansas and taphonomic comparison with modern Limulus: Lethaia, v. 33, p. 129-141.

Baccour, H., Medhioub, M., Jamoussi, F., Mhiri, T., and Daoud, A., 2008, Mineralogical evaluation and industrial applications of the Triassic clay deposits, Southern Tunisia: Materials Characterization, v. 59, p. 613-1622.

Biely, A., and Rakus, M., 1991, Les fossiles du Trias gréseux de la Jeffara (Sud-tunisien): Notes du Service Géologique de Tunisie, v. 58, p. 5-9.

Bleicher, M., 1897, Sur la découverte d'une nouvelle espèce de Limule dans les marnes irisees 74 de Lorraine: Bulletin of the Society of Science de Nancy, v. 2, p. 116-126.

Błażejowski, B., 2015, The oldest species of the genus Limulus from the Late Jurassic of Poland, in Carmichael, R.H, Botton, M.L, Shin, P.K.S., and Cheung, S.G., eds., Changing Global Perspectives on Biology, Conservation, and Management of Horseshoe Crabs: New York, Springer, p. 3-14.

Błażejowski, B., Gieszcz, P., Brett, C.E., and Binkowski, M., 2015, A moment from before $365 \mathrm{Ma}$ frozen in time and space: Scientific Reports, v. 5, 14191; doi: 10.1038/srep14191

Błażejowski, B., Gieszcz, P., and Tyborowski, D., 2016, New finds of wellpreserved Tithonian (Late Jurassic) fossils from the Owadów-Brzezinki Quarry, Central Poland: a review and perspectives: Volumina Jurassica, v. 14, p. 123-132. doi: 10.5604/17313708.1222641

Botton, M.L., 1984, Importance of predation by horseshoe crabs, Limulus polyphemus, to an intertidal sand flat community: Journal of Marine Research, v. 42, p. 139-161.

Botton, M.L., and Ropes, J.W., 1989, Feeding ecology of horseshoe crabs on the continental shelf, New Jersey to North Carolina: Bulletin of Marine Science, v. 45 , p. $637-647$.
Bouaziz, S., 1986, La déformation dans la plateforme du Sud Tunisien (Dahar et Jeffara): Approche multiscalaire et pluridisciplinaire [graduate thesis]: Tunis, Tunisia, Université Tunis, $180 \mathrm{p}$.

Bouaziz, S., Barrier, E., Soussi, M., Turki, M.M., and Zouari, H., 2002, Tectonic evolution of the northern African margin in Tunisia from paleostress data and sedimentary record: Tectonophysics, v. 357, p. 227-253.

Braun, C.F., 1860, Die Thiere in den Pflanzenschiefern der Gegend von Bayreuth: 1771, Zoologica Fundamenta.

Busson, G., 1967, Le Mésozoïque saharien, lere partie: L'Extreme Sud tunisien: Centre National de la Recherche Scientifique de France, v. 8, 194 p.

Chen, Z.Q., and Benton, M.J., 2012, The timing and pattern of biotic recovery following the end-Permian mass extinction: Nature Geoscience, v. 5 , p. 375-383. doi: 10.1038/ngeo 1475

Clarkson, M., Kasemann, S., Wood, R., Lenton, T., Daines, S., Richoz, S., Ohnemueller, F., Meixner, A., Poulton, S., and Tipper, E., 2015, Ocean acidification and the Permo-Triassic mass extinction: Science, v. 348, p. 229-232.

Courel, L., Ait Salem, H., Benaouiss, N., Et-Touhami, M., Fekirine, B., Oujidi, M., Soussi, M., and Tourani, A., 2003, Mid-Triassic to Early Liassic clastic/ evaporitic deposits over the Maghreb Platform: Palaeogeography, Palaeoclimatology, Palaeoecology, v. 196, p. 157-176.

DiMichele, W.A., Pfefferkorn, H.W., and Gastaldo, R.A., 2001, Response of Late Carboniferous and Early Permian plant communities to climate change: Annual Review of Earth and Planetary Sciences, v. 29, p. 461-487.

Dridi, M., and Maazaoui, A., 2003, Environment and paleogeography of the Triassic of Ghadamis Basin: a case study, in Salem, M.J., and Oun, K.M., eds., The Geology of Northwest Libya, v. 1, p. 139-170.

Dunbar, C.O., 1923, Kansas Permian insects. Part 1. The geologic occurrence and the environment of the insects: American Journal of Science 5th Ser., v. 7, p. 171-209.

Ehlinger, G.S., and Tankersley, R.A., 2009, Ecology of horseshoe crabs in microtidal lagoons, in Tanacredi, J.T., Botton, M.L., and Smith, D.R., eds., Biology and Conservation of Horseshoe Crabs: New York, Springer, p. $149-162$.

Erwin, D.H., 1993, The Great Paleozoic Crisis: Life and Death in the Permian: New York, Columbia University Press, 327 p.

Erwin, D.H., 2006, Extinction: How Life on Earth Nearly Ended 250 Million Years Ago: Princeton, NJ, Princeton University Press, 320 p.

Feldmann, R.M., Schweitzer, C.E., Dattilo, B., and Farlow, J.O., 2011, Remarkable preservation of a new genus and species of limuline horseshoe crab from the Cretaceous of Texas, USA: Palaeontology, v. 54, p. $1337-1346$.

Filipiak, P., and Krawczyński, W., 1996, Westphalian xiphosurans (Chelicerata) from the Upper Silesia Coal Basin of Sosnowiec, Poland: Acta Palaeontologica Polonica, v. 41, p. 413-425.

Foster, W.J., and Twitchett, R.J., 2014, Functional diversity of marine ecosystems after the late Permian mass extinction event: Nature Geoscience, v. 7, p. 233-238.

Fritsch, K., 1906, Beitrag zur Kenntnis der Tierwelt der deutschen Trias: Abhandlungen der naturforschender Gesellschaft Halle, v. 24, p. 220-285.

Gaillard, C., 2011, A giant limulid trackway (Kouphichnium lithographicum) from the lithographic limestones of Cerin (Late Kimmeridgian, France): ethological and environmental implications: Swiss Journal of Geosciences, v. 104 , p. 57-72.

Gall, J.C., and Grauvogel-Stamm, L., 1999, Paläoökologie des Oberen Buntsandsteins am Westrand des Germanischen Beckens: Der Voltziensandstein im nordöstlichen Frankreich als deltaische Bildung, in Hauschke, N., and Wilde, V., eds., Trias: Eine ganz andere Welt: München, Verlag Friedrich Pfeil, p. 283-298.

Gall, J.C., and Grauvogel-Stamm, L., 2005, The early Middle Triassic 'Grès à Voltzia' Formation of eastern France: a model of environmental refugium: Paléontologie générale (Paléoécologie), v. 4, p. 637-652.

Haq, B.U., and Shutter, S.R., 2008, A chronology of Paleozoic sea-level changes: Science, v. 322, p. 64-68.

Hauschke, N., and Wilde, V., 1987, Paleolimulus fuchsbergensis n. sp. (Xiphosura, Merostomata) aus der oberen Trias von Nordwestdeutschland, mit einer Übersicht zur Systematik und Verbreitung rezenter Limuliden: Paläontologische Zeitschrift, v. 61, p. 87-108.

Hauschke, N., and Wilde, V., 2000, Limulidenreste aus dem Unteren Butsandstein (Bernburg-Formation) von Beesenlaubingen (Sachsen-Anhalt): Hallesches Jahrbuch für Geowissenschaften B, v. 22, p. 87-90.

Hauschke, N., and Wilde, V., 2008, Limuliden aus dem Oberen Buntsandstein von Süddeutschland: Hallesches Jahrbuch für Geowissenschaften, v. 30, p. $21-26$.

Hauschke, N., Wilde, V., and Brauckmann, C., 2004, Triassic limulids from Madagascar-missing links in the distribution of Mesozoic Limulacea: Neues Jahrbuch für Geologie und Paläontologie, Monatshefte, v. 2, p. 87-94. 
Hauschke, N., Oosterink, H.W., and Wilde, V., 2009, Erster Nachweis eines Limuliden (Xiphosura, Limulacea) im Muschelkalk von Winterswijk (Niederlande): Der Aufschluss, v. 60, p. 13-23.

Holland, F.D., Erickson, J.M. Jr., and O'Brien, D.E., 1975, Casterolimulus: a new Late Cretaceous link in limulid lineage: Bulletins of American Paleontology, v. 67, p. 235-249.

Hu, S.-X., Zhang, Q.-Y., Chen, Z.-Q., Zhou, C.Y., Lü, T., Xie, T, Wen, W., Huang, J.-Y., and Benton, M.J., 2011, The Luoping biota: exceptional preservation, and new evidence on the Triassic recovery from end-Permian mass extinction: Proceedings of the Royal Society, Series B, v. 278, p. 2274-2282. doi: 10.1098/rspb.2010.2235

Kamoun, F., Peybernès, B., Martini, R., Zaninetti, L., Vila, J.-M., Trigui, A., and Rigane, A., 1998, Associations de foraminifères benthiques dans les séquences de dépôt du Trias moyen? Supérieur de l'Atlas tunisien central et méridional: Geobios, v. 31, p. 703-714

Kamoun, F., Peybernès, B., and Fauré, P., 1999, Evolution paléogéographique de la Tunisie saharienne et atlasique au cours du Jurassi que: Comptes Rendus de l'Académie des Sciences, v. 328, p. 547-552.

Kamoun, F., Peybernès, B., Ciszak, R., and Calzada, S., 2001, Triassic palaeogeography of Tunisia: Palaeogeography, Palaeoclimatology, Palaeoecology, v. 172, p. 223-242.

Kilani-Mazraoui, F., Razgallah-Gargouri, S., and Mannai-Tayech, B., 1990, The Permo-Triassic of Southern Tunisia-biostratigraphy and palaeoenvironment: Review of Palaeobotany and Palynology, v. 66, p. 273-291.

Kin, A., and Błażejowski, B., 2014, The Horseshoe Crab of the genus Limulus: living fossil or stabilomorph?: PLoS ONE, v. 9(10): e108036. doi: 10.1371/ journal.pone. 0108036

Knoll, A.H., Bambach, R.K., Payne, J.L., Pruss, S., and Fischer, W., 2007, Paleophysiology and end-Permian mass extinction: Earth and Planetary Science Letters, v. 256, p. 295-313. doi: 10.1016/j.epsl.2007.02.018

Lamsdell, J.C., 2013, Revised systematics of Palaeozoic 'horseshoe crabs' and the myth of monophyletic Xiphosura: Zoological Journal of the Linnean Society, v. 167, p. 1-27.

Lamsdell, J.C., 2016, Horseshoe crab phylogeny and independent colonizations of fresh water: ecological invasion as a driver for morphological innovation: Palaeontology, p. 181-144. doi: 10.1111/pala.12220

Lamsdell, J.C., and McKenzie, S.C., 2015, Tachypleus syriacus (Woodward)—a sexually dimorphic Cretaceous crown limulid reveals underestimated horseshoe crab divergence times: Organisms Diversity \& Evolution, v. 15, p. 681-693.

Lamsdell, J.C., and Selden, P.A., 2016, From success to persistence: identifying an evolutionary regime shift in the diverse Paleozoic aquatic arthropod group Eurypterida, driven by the Devonian biotic crisis: Evolution, v. 71, p. 95-110.

Lange, W., 1923, Über neue Fossilfunde aus der Trias von Göttingen: Zeitschrift Deutsche Geologische Gesellschaft, v. 74, 162 p.

Latreille, P.A., 1802, Histoire Naturelle Generale et particuliere des Cristaces et Insectes: Paris, Dufact, $467 \mathrm{p}$.

Latreille, P.A., 1829, Le Règne animal. (Ed. Cuvier, C.L.C.F.D.). 2nd ed., vol. 4. Crustacés, arachnides et partie des insectes: Paris, Déterville, 1584 p.

Leach, W.E., 1819, Entomostraca. in Cuvier, F.G., ed., Dictionnaires des Sciences Naturelles: Paris, F.G. Levrault, v. 14, p. 524-543.

Loveland, R.E., and Botton, M.L., 2015, Sea level rise in Delaware Bay, U.S.A.: adaptations of spawning horseshoe crabs (Limulus polyphemus) to the glacial past, and the rapidly changing shoreline of the bay, in Carmichael, R.H, Botton, M.L, Shin, P.K.S., and Cheung, S.G., eds., Changing Global Perspectives on Biology, Conservation, and Management of Horseshoe Crabs: New York, Springer, p. 41-63.

Meischner, K.D., 1962, Neue Funde von Psammolimulus gottingensis (Merostomata, Xiphosura) aus dem Mittleren Buntsandstein von Göttingen: Paläontologische Zeitschrift, v. 36, p. 185-193.

Oppel, A., 1862, Ueber Fährten lithographischen Schiefer (Ichnites lithographicus): Paläeontologische aus dem Mitteilungen aus dem Museum des Koeniglich Bayerischen Staates, v. 1, p. 121-125.

Peyser, C.E., and Poulsen, C.J., 2008, Controls on Permo-Carboniferous precipitation over tropical Pangaea: a GCM sensitivity study: Palaeogeography, Palaeoclimatology, Palaeoecology, v. 268, p. 181-192.

Pickett, J.W., 1984, A new freshwater limuloid from the Middle Triassic of New South Wales: Palaeontology, v. 27, p. 609-621.

Ponomarenko, A.G., 1985, King crabs and eurypterids from the Permian and Mesozoic of the USSR: Paleontologiceskij Zurnal, v. 3, p. 115-118.

Raymond, P.E., 1944, Late Paleozoic xiphosurans: Bulletin of the Museum of Comparative. Zoology at Harvard College, v. 94, p. 475-508.

Riek, E.F., 1955, A new xiphosuran from the Triassic sediments at Brookvale, New South Wales: Records of the Australian Museum, v. 23, p. 281-282.

Riek, E.F., 1968, Re-examination of two arthropod species from the Triassic of Brookvale, New South Wales: Records of the Australian Museum, v. 27, p. $313-321$.
Riek, E.F., and Gill, E.D., 1971, A new xiphosuran genus from Lower Cretaceous freshwater sediments at Koonwarra, Victoria, Australia: Palaeontology, v. 14, p. 206-210.

Romero, A., and Boada, L., 1977, Tarracolimulus rieki nov. gen., nov. sp., nuevo limulido del Triásico de Montral-Alcover (Tarragona): Cuadernos de Geología Ibérica, v. 4, p. 239-246.

Röhling, H.G., and Heunisch, C., 2010, Der Buntsandstein. Eine lebensfeindliche Wüste oder doch mehr?: Biologie in Unserer Zeit, v. 40, p. 268-276. doi. 10.1002/biuz.201010428

Rudkin, D.M., Young, G.A., and Nowlan, G.S., 2008, The oldest horseshoe crab: a new xiphosurid from late Ordovician Konservat-Lagerstätten deposits, Manitoba, Canada: Palaeontology, v. 51, p. 1-9.

Sallan, L., and Galimberti, A.K., 2015, Body-size reduction in vertebrates following the end-Devonian mass extinction: Science, v. 350, p. 812-815.

Scheffler, K., Hoernes, S., and Schwark, L., 2003, Global changes during Carboniferous-Permian glaciation of Gondwana: linking polar and equatorial climate evolution by geochemical proxies: Geology, v. 31, p. $605-608$.

Schimper, W.P., 1853, Paleontologica alsatica ou fragments paléontologiques des différents terrains stratifies qui se recontrent en Alsace: Mémoires de la Société du Muséum d'Histoire Naturelle de Strasbourg, v. 4, p. 1-10.

Schweigert, G., 1998, Die Spurenfauna des Nusplinger Plattenkalks (Oberjura, Schwäbische Alb): Stuttgarter Beiträge zur Naturkunde, Serie B, v. 262, p. 1-47.

Shen, S.Z., Cao, C., Henderson, C.M., Wang, X., Shi, G.R., Wang, Y., and Wang, W., 2006, End-Permian mass extinction pattern in the northern peri-Gondwanan region: Palaeoworld, v. 15, p. 3-30.

Shuster, Carl N. Jr., 1982, A pictorial review of the natural history and ecology of the horseshoe crab, Limulus polyphemus, with reference to other Limulidae, in Bonaventura, J., Bonaventura, C., and Tesh, S., eds., Physiology and Biology of Horseshoe Crabs: New York, Alan R. Liss, p. 1-52.

Soussi, M., Abbes, Ch., and Belayouni, H., 1998, Sedimentary record of sea level changes and associated organic-rich facies on the southern Tehyan margin: the Upper Triassic of central Tunisia: Africa Geoscience Review, v. 5 , p. $275-285$.

Soussi, M., Cirilli, S., and Abbes, Ch., 2001, Nouvelles données palynologiques sur la formation Rhéouis: conséquences sur les corrélations et la paléogéographie de la Tunisie au Trias supérieur: Notes du Service Géologique, Tunisie, v. 67, p. 87-105.

Soussi, M., Niedźwiedzki, G., Tałanda, M., Dróżdż, D., Sulej, T., Boukhalfa, K., Mermer, J., and Błażejowski, B., 2016, Middle Triassic (Anisian-Ladinian) Tejra red beds and Late Triassic (Carnian) carbonate sedimentary records of southern Tunisia, Saharan Platform: biostratigraphy, sedimentology and implication on regional stratigraphic correlations: Marine and Petroleum Geology, v. 79, p. 222-256.

Stanley, S.M., and Powell, M.G., 2003, Depressed rate of origination and extinction during the late Paleozoic ice age: a new state for the global marine ecosystem: Geology, v. 31, p. 877-880.

Størmer, L., 1952, Phylogeny and taxonomy of fossil horseshoe crabs: Journal of Paleontology, v. 26, p. 630-640.

Twitchett, R.J., Looy, C.V., Morante, R., Visscher, H., and Wignall, P.B., 2001, Rapid and synchronous collapse of marine and terrestrial ecosystems during the end-Permian biotic crisis: Geology, v. 29, p. 351-354.

Van Roy, P., Orr, P.J., Botting, J.P., Muir, L.A., Vinther, J., Lefebvre, B., el Hariri, K., and Briggs, D.E.G., 2010, Ordovician faunas of Burgess Shale type: Nature, v. 465 , p. $215-218$.

Veron, J.E.N., 2008, Mass extinctions and ocean acidification: biological constraints on geological dilemmas: Coral Reefs, v. 27, p. 459-472.

Vía, L., 1987, Artropodos fosiles Triasios de Alcover-Montral. II. Limulidos: Cuadernos Geología Ibérica, v. 11, p. 281-292.

Vía Boada, L., and De Villalta, J.F., 1966, Heterolimulus gadeai, nov. gen., nov. sp., représentant d'une nouvelle famille de Limulacés dans le Trias d'Espagne: Compte rendu de Séances de la Société géologique de France, v. 2 , p. $57-59$.

Wesselingh, F.P., 2007, Long-lived lake molluscs as island faunas: a bivalve perspective, in Renema, W., ed., Biogeography, Time, and Place: Distributions, Barriers, and Islands. Berlin, Springer, p. 275-314.

Zhang, Q.Y., Hu, S., Zhou, C.Y., Lü, T., and Bai, J.K., 2009, First occurrence of horseshoe crab (Arthropoda) fossils from China: Progress in Natural Science, v. 19, p. 1090-1093. [In Chinese]

Zittel, K., von, 1885, Handbuch der Palaeontologie: Palaeozoology: München and Leipzig, Druck und Verlag von R. Oldenbourg, v. 2, p. 640-645.

Accepted 18 April 2017 